\title{
Development perspectives for biogas production from agricultural waste in Friuli Venezia Giulia (Nord-East of Italy)
}

\author{
D. dell'Antonia, ${ }^{1}$ S.R.S. Cividino, ${ }^{1}$ A. Carlino, ${ }^{2}$ R. Gubiani, ${ }^{1}$ G. Pergher ${ }^{1}$ \\ 'University of Udine, Department of Agriculture and Environmental Sciences Udine, Italy; \\ ${ }^{2}$ Regione Friuli Venezia Giulia, Italy
}

\section{Abstract}

The latest directives of the Energy and Environment Policy of the European Union (EU) established a new framework for renewable sources (Directive EC 28/2009; European Commission, 2009). The Italian Energy Action Plan of 2010 set a target of at least 17\% of total energy generated from renewable sources by 2020 . In this context biogas from waste and biomass is a potential energy source that can be used for the production of heat, electricity and fuel. The objective of this work was to determine the potential energy production from anaerobic digestion of animal wastes and agricultural residues in Friuli Venezia Giulia (Nord-East Italy).

For an assessment of biogas as an energy source, based on direct conversion by agricultural farms, it is important to establish the amount of the waste. In this study, biogas amount which can be obtained was calculated for all municipalities in the Friuli Venezia Giulia Region (North-East of Italy) by using the number of livestock animals, the cereal area for agricultural residues and also considering various criteria such as the rate of dry matter and availability.

The calculated regional biogas potential is about $187(\mathrm{~N}) \mathrm{Gm} 3$ when using animal waste, straw and corn stalk. The potential of biogas energy equivalent of Friuli Venezia Giulia is about 3600 TJ (LHV) may be able to replace $2.6 \%$ of final energy consumption in Friuli Venezia Giulia (3 339 ktoe) and about 10\% of the final electricity consumption (864 ktoe) considering an electrical efficiency of $30 \%$ with the biogas engine.

\section{Introduction}

The latest directives of the Energy and Environment Policy of the European Union (EU) established a new framework for renewable

Correspondence: Daniele dell'Antonia, University of Udine, Department of Agriculture and Environmental Sciences, Via delle Scienze, 208 - 33100 Udine, Italy

E-mail: daniele.dellantonia@uniud.it

Key words: biogas, animal waste, straw, corn stalk, feedstock

(C) Copyright D. dell'Antonia et al., 2013

Licensee PAGEPress, Italy

Journal of Agricultural Engineering 2013; XLIV(s2):e112

doi:10.4081/jae.2013.s2.e112

This article is distributed under the terms of the Creative Commons Attribution Noncommercial License (by-nc 3.0) which permits any noncommercial use, distribution, and reproduction in any medium, provided the orig- sources (Directive EC 28/2009; European Commission, 2009). The Italian Energy Action Plan of 2010 set a target of at least $17 \%$ of total energy generated from renewable sources by 2020 . In this context biogas from waste and biomass is a potential energy source that can be used for the production of heat, electricity and fuel. Regarding this, Italy took its first steps at the beginning of the $1980 \mathrm{~s}$ when realisation of biogas production plants from animal waste was essentially aimed at reducing environmental impact in the agricultural sector rather than providing a clean energy source. At present the situation has changed: while the importance of environmental asp ects is still fully recognised, there is now the additional need to increase the use of renewable energy sources in rural areas (Tricase et al., 2009).

The number of anaerobic digestion plants in Italy hasincreased, in recent years, thanks to the old Italian energy law from 244/2007, which provided an all-inclusive feed-in tariff(280 €/MWh for biomass) for electricity production from agricultural biomas s, regardless of the feedstock type and the power of the plants.In 2010, some 600 plants in Italy were producing biogas, with a total installed electric power of 350 MW(e) approx. (Piccinini, 2010). Of these plants, 58\% of which were working in co-digestion of manure with energy crops and agro-industrial residues.

In July 2012, Italy adopted a new regulation for the production of electricity from bioma ss, making the public support higher if the production of biogas is derived entirely from animal waste and agricultural by-products (Ministry of Economic Development, 2012).

In relation to the biogas potential from agricultural by-products is important to identify the best farm for the technical and economic convenience of small biogas plants. The objective of this work was to determine the potential energy production from anaerobic digestion of agricultural by-products (animal wastes and agricultural residues) in Friuli Venezia Giulia (Nord-East Italy).

\section{Materials and methods}

The agricultural land area in Friuli Venezia Giulia is 218443 ha (26.5\% of total land area; Istat, 2010) with 22316 agricultural farms (average: 9.8 ha per farm). Only 3343 farms (15.0\%) are raising livestock, including cattle (61.7\% of farms), pigs (17.5\%), poultry (11.7\%), small ruminants (sheep and goats, 8.0\%), and rabbits (4.5\%). Small ruminants, equines and rabbits were not included in the present analysis.Cattle has the largest share with 89162 head, $88 \%$ of all ruminants. In poultry, $83 \%$ aremeat chickens (broilers), $8 \%$ are laying hens, $6 \%$ are turkeys for a total of 6951512 pieces. Finally, pigs are present with 216430 animal (Table 1).

The total number of cattle, pig and poultry with the relative categorieswas determined using available data for 218 municipaliti es in Friuli Venezia Giulia (Istat, 2010). These numbers were then used to estimate the potential production of biogas and its energy content for each of the municipalities. There are severalfactors whichaffect the amount of waste and biogas obtainable during livestock operations. 
These factors include the type and age of animal, body weight, type of breeding, total solids ratio, volatile solids ratio and the availability of waste and biogas yields. The average body weight for the different animal categories was determined using the standards reportedin Italian Law 109/2007 (Table 2).

In the calculation of the amou nt of waste, the number of animals in each category (cattle, pigs and poultry) and their sub-categories (age of the animal) were multiplied by the body weight to determine the tons of live weight. The live weight for each category(LW, in ton), was calculated as:

$\mathrm{LW}=\mathrm{n}^{\circ} \cdot \mathrm{lW}$

Table 1. The number of livestock farms and total animal numbers for cattle, pig and poultry in Friuli Venezia Giulia.

\begin{tabular}{lccc} 
Animaltype & $\begin{array}{c}\text { Live } \\
\text { stock farms }\end{array}$ & $\begin{array}{c}\text { Number of } \\
\text { animals }\end{array}$ & $\begin{array}{c}\text { Animals } \\
\text { per live stock farm }\end{array}$ \\
Cattle & 2050 & 89162 & 43 \\
Pig & 586 & 216430 & 369 \\
\hline Equine & 582 & 2815 & 5 \\
Poultry & 392 & 6951512 & 17733 \\
\hline Rabbit & 152 & 670383 & 4410 \\
Goats & 141 & 3285 & 23 \\
\hline Sheep & 126 & 10890 & 86 \\
Italian buffalo & 15 & 1449 & 97 \\
\hline Ostrich & 2 & 251 & 126 \\
\hline
\end{tabular}

Where:

$\mathrm{n}^{\circ}$, is the number of animal in each category;

lw, in tons, is the live weight per head in each animal category.

According to the standards set by Italian Law 109/2007, concerning the agronomic use of livestock effluents, were defined the wet waste per body weight of each type and age of the animals (annual amounts of wet waste were determined in relation to the type of breeding for each category). The livestock operations slurry (liquid material) and manure (shovelable materials) were considered for the waste yield (Table 3).The amount of annual slurry( $\mathrm{S}$, in $\mathrm{m} 3$ ) was calsutaled as:

$\mathrm{S}=\Sigma(\mathrm{LW} \cdot \mathrm{Sb} \cdot \mathrm{B}$

Where:
$\mathrm{LW}$, in tons, is the live weight for each category;

$\mathrm{Sb}$, in $\mathrm{m}^{3} \mathrm{t}^{-1}$, is the slurry per unit live weight for the type of breeding in each category;

$\mathrm{Br}$, in \%, is the percentage of the type of breeding.

The amount of annual manure $\left(\mathrm{M}\right.$, in $\left.\mathrm{m}^{3}\right)$ wascalsutaled as:

$\mathrm{M}=\Sigma(\mathrm{LW} \cdot \mathrm{Sb} \cdot \mathrm{Br})$

Where:

$\mathrm{LW}$, in tons, is the live weight for each category;

$\mathrm{Mb}$, in $\mathrm{m} 3 \mathrm{t}^{-1}$, is the manure per live weight for the type of breeding in each category;

$\mathrm{Br}$, in \%, is the percentage of the type of breeding.

The biogas yields from cattle, pig and poultry were calculated according to annual amounts of the organic matter in the slurry and manure waste (Table 2). A map of biogas potential production has been produced using GIS-based software. The annual amount of potential bi ogas $\left(\mathrm{B}\right.$, in $\left.\mathrm{m}^{3}\right)$ has been derived from:

$\mathrm{B}=(\mathrm{S} \cdot \mathrm{Es})+(\mathrm{M} \cdot \mathrm{Em})$

Where:

$\mathrm{S}$, in $\mathrm{m}^{3}$, is the amount of annual slurry;

$\mathrm{M}$, in $\mathrm{m}^{3}$, is the amount of annual manure;

Es, in $\mathrm{m}^{3}\left(\mathrm{~m}^{-3} \mathrm{~m}^{-3}\right)$, is the efficiency of biogas production fromslurry;

$\mathrm{Em}$, in $\mathrm{m} 3\left(\mathrm{~m}^{-3} \mathrm{~m}^{-3}\right)$, is the efficiency of biogas production frommanure.

The data of the biogas obtainable during livestock operations were correlated with the agricultural residues. Operational scenarios provided the utilisation of straw and corn stalk. This allowed to identify the technical potential for the biogas production from the agricultural waste in Friuli Venezia Giulia and afterwards evaluate the economic feasibility of biogas plants in relation to different situations of the area (higher public support for the production of electricity when using by-products).

\section{Results}

The biogas potential annual production according to categories and number of animals in designated municipalities in Friuli Venezia Giulia in is presented in Figure 1.

The calculated regional biogas potential is about $38.4(\mathrm{~N}) \mathrm{Mm}^{3}$ when using only animal waste where $51 \%$ of total energy potential is of cattle origin, $32 \%$ from pig and $17 \%$ of poultry origin. The potential of biogas energy equivalent of Friuli Venezia Giulia is about 777 TJ (LHV) (Table 4).

Table 2. Waste properties and biogas yields of slurry and manure by type of animal.

\begin{tabular}{|c|c|c|c|c|c|c|}
\hline Feedstock & $\begin{array}{l}\text { DM content } \\
\text { (\% a.r.) }\end{array}$ & $\begin{array}{c}\text { Organic } \\
\text { DM content ( } \% \text { a.r.) }\end{array}$ & $\begin{array}{c}\text { Specific } \\
\text { weight }\left(t / m^{3}\right)\end{array}$ & $\begin{array}{c}\text { Biogas } \\
\left(\mathrm{Nm}^{3} \mathrm{t}^{-1} \text { Organic DM) }\right.\end{array}$ & $\begin{array}{c}\text { Methane(\%) } \\
(\%)\end{array}$ & $\begin{array}{c}\text { LHV } \\
\left(\mathrm{MJ} / \mathrm{m}^{3}\right)\end{array}$ \\
\hline Cattleslurry & 8.5 & 6.75 & 1 & 230 & 55 & 19.6 \\
\hline Cattlemanure & 18 & 14.25 & 0.3 & 250 & & \\
\hline Pigslurry & 6.1 & 4.9 & 1 & 355 & $55-60$ & 20.5 \\
\hline Pigmanure & 22.5 & 18.75 & 0.3 & 450 & & \\
\hline Poultryslurry & 19.5 & 14.9 & 1 & 300 & 60 & 21.4 \\
\hline Poultrymanure & 32.25 & 24.2 & 0.3 & 400 & & \\
\hline Cornstalks & 86 & 62 & 0.4 & 500 & 54 & 19.3 \\
\hline Straw & 87.5 & 76 & 0.04 & 390 & 54 & 19.3 \\
\hline
\end{tabular}


Table 3. The live weight weightand waste yield of the animalsin each category.

\begin{tabular}{|c|c|c|c|c|c|}
\hline \multirow[t]{2}{*}{ Animal type } & \multirow[t]{2}{*}{ Categories } & \multirow[t]{2}{*}{ Live weight (kg) } & \multirow[t]{2}{*}{ Housing system } & \multicolumn{2}{|c|}{ Waste yield $\left(\mathrm{m}^{3}\right.$ t.l.w. $\left.{ }^{-1}\right)$} \\
\hline & & & & Slurry & Manure \\
\hline \multirow[t]{10}{*}{ Cattle } & $<1$ year & 150 & Freestall with litter & 4 & 22 \\
\hline & & & Freestallwithoutlitter & 22 & - \\
\hline & 1-2 years & 450 & Freestall with litter & 10 & 26.5 \\
\hline & & & Freestallwithoutlitter & 26 & - \\
\hline & $>2$ years & 550 & Freestall with litter & 10 & 26.5 \\
\hline & & & Freestallwithoutlitter & 26 & - \\
\hline & Cows & 600 & Tiestall with litter & 9 & 35 \\
\hline & & & Tiestallwithoutlitter & 33 & - \\
\hline & & & Freestall with litter & 14,5 & 32 \\
\hline & & & Freestallwithoutlitter & 33 & \\
\hline \multirow[t]{30}{*}{ Pig } & $20-50 \mathrm{~kg}$ & 35 & Partially-slatted & 44 & - \\
\hline & & & Fully-slatted & 37 & - \\
\hline & & & Straw-bedded & 3 & 28 \\
\hline & & & Concrete floor & 64 & - \\
\hline & $50-80 \mathrm{~kg}$ & 65 & Partially-slatted & 44 & - \\
\hline & & & Fully-slatted & 37 & - \\
\hline & & & Straw-bedded & 3 & 28 \\
\hline & & & Concrete floor & 64 & - \\
\hline & $80-110 \mathrm{~kg}$ & 95 & Partially-slatted & 44 & - \\
\hline & & & Fully-slatted & 37 & - \\
\hline & & & Straw-bedded & 3 & 28 \\
\hline & & & Concrete floor & 64 & - \\
\hline & $>110 \mathrm{~kg}$ & 110 & Partially-slatted & 44 & - \\
\hline & & & Fully-slatted & 37 & - \\
\hline & & & Straw-bedded & 3 & 28 \\
\hline & & & Concrete floor & 64 & - \\
\hline & Boar & 250 & Fully-slatted & 37 & - \\
\hline & & & Straw-bedded & - & 31 \\
\hline & Sow & 180 & Partially-slatted & 44 & - \\
\hline & & & Fully-slatted & 37 & - \\
\hline & & & Straw-bedded & - & 31 \\
\hline & & & Concrete floor & 73 & - \\
\hline & Gilt & 100 & Partially-slatted & 44 & - \\
\hline & & & Fully-slatted & 37 & - \\
\hline & & & Straw-bedded & - & 31 \\
\hline & & & Concrete floor & 64 & - \\
\hline & Layinghens & 1.9 & Deeplitter with Slatted & 0.15 & 18 \\
\hline & & & Cage Battery with belt system & 0.05 & 19 \\
\hline & & & Cage Battery with slurry deep pit & 22 & - \\
\hline & & & Cage Battery with manure deep pit & 0.1 & 17 \\
\hline \multirow[t]{5}{*}{ Poultry } & Pullets & 1 & Deeplitter & 1.2 & 19 \\
\hline & Broilers & 1 & Deeplitter & 1.2 & 19 \\
\hline & Pharaoh & 1 & Deeplitter & 1.7 & 13 \\
\hline & Goose & 6.5 & Deeplitter & 0.9 & 15 \\
\hline & Turkeys & 6.7 & Deeplitter & 0.9 & 15 \\
\hline
\end{tabular}




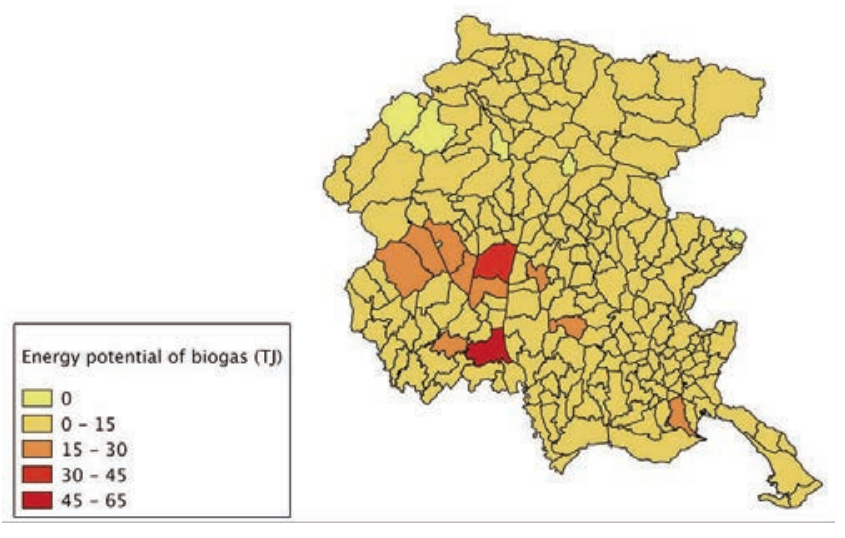

Figure 1. Distributions of the energy potential of biogas production in Friuli Venezia Giulia

In the map the areas with high potential for biogas production are concentrated in Central-Eastern part of the Region. In particular. an area includingsevenmunicipalities (San Vito al Tagliamento, Spilimbergo, Maniago, Montereale Valcellina, San Giorgio alla Richinvelda, Aviano and Vivaro) presents a high potential due to the presence of intensive farming. The area has the potential of about 10.6 (N) $\mathrm{Mm}^{3}$ (28\% of the regional potential). In particular. San Vito al Tagliamento for pig and poultry.whileSpilimbergo for cattle and poultry.

The biogas potential from agricultural by-products is about 187 (N) $\mathrm{Mm}^{3}$. where $21 \%$ from animal waste and $79 \%$ from agricultural residues. The energy potential of biogas produced from agricultural by-products may be able to replace the $2.6 \%$ of final energy consumption in Friuli Venezia Giulia (3 339 ktoe) and about 3\% of the final electricity consumption (864 ktoe) considering a electrical conversion efficiency of $30 \%$.

\section{Conclusions}

This work has been a first step in a more complete evaluation of the biogas potential in Friuli Venezia Giulia, which will analyse biogas yields depending on different feedstocks (triticale, straws, agro-industrial waste), plant sizes and logistic solutions, in order to assessthe full technical and economic convenience of small biogas plants in the regional area (100-250 $\mathrm{kWe})$.In this conte $\mathrm{xt}$ it is important that the public contribution continue to support biogas plants in order to diversify energy production from the agricultural sector. In fact,the establishment of biogas plants can be a solution to support the agri-food sector (milk, eggs, cheese, meat,etc) in Friuli Venezia Giulia.
Table 4. The total biogas production and relative energy potential from animal waste in Friuli Venezia Giulia

\begin{tabular}{|c|c|c|c|c|}
\hline Animaltype & \multicolumn{2}{|c|}{ Biogas production } & Energy potentia & $\begin{array}{l}\text { ntial } \\
(\%)\end{array}$ \\
\hline Cattle & 19425929 & 51 & 380748 & 49 \\
\hline Pig & 12455854 & 32 & 255345 & 33 \\
\hline Poultry & 6588133 & 17 & 140986 & 18 \\
\hline Total & 38469916 & 100 & 777079 & 100 \\
\hline
\end{tabular}

Table 5. The total biogas production and relative energy potential from animal waste in Friuli Venezia Giulia

\begin{tabular}{lcccc} 
& Cornstalk & Straw & Animalwaste & Total \\
Area (ha) & 73846 & 15974 & - & - \\
By-products (t/year) & 406153 & 74949 & 2416102 & 2897204 \\
\hline Biogas ((N) Mm3/year) & 126 & 22 & 38 & 187 \\
Energy potential (TJ/year) & 2430 & 429 & 777 & 3636 \\
\hline Share of energypotential (\%) & 67 & 12 & 21 & 100 \\
\hline
\end{tabular}

\section{References}

European Commission. 2009. Directive EC 28/2009 of the european parliament and of the council on the promotion of the use of energy from renewable sources and amending and subsequently repealing Directives 2001/77/EC and 2003/30/EC. In: Official Journal. L 140. 05/06/2009. pp. 16-62.

Italian Regulation. 2010. Italian Energy Action Plan of 2010 required by Directive EC 28/2009. Ministry of Economic Development.

Tricase C.. Lombardi M. 2009. State of the art and prospects of Italian biogas production from animal sewage: Technical-economic considerations. Renewable Energy 34: 477-485.

Piccinini. 2010. Available from:http://www.progettobiomasse.it Accessed: May 2012.

Italian Regulation. 2012. Decreto Ministeriale of 6 July 2012. Modalità di incentivazione della produzione di energia elettrica da impianti alimentati da fonti rinnovabili.diverse da quella solare fotovoltaica.con potenza non inferiore a $1 \mathrm{~kW}$. Ministry of Economic Development.

Istat Data Warehouse. 2010. Available from: http://dati-censimentoagricoltura.istat.itAccessed: May 2012.

Italianregulation. 2006. Degree 7 April 2006. Criteri e norme tecniche generali per la disciplina regionale dell'utilizzazione agronomica degli effluenti di allevamento.di cui all'articolo 38 del decreto legislativo 11 maggio 1999.n. 152. Gazzetta ufficiale n. 109 del $12 / 05 / 2006$.

Fantozzi F.. Buratti C. 2009. Biogas production from different substrates in an experimental Continuously Stirred Tank Reactor anaerobic digester.Bioresource Technology 100: 5783-5789.

Onurbas Avcioglu A.. Türker U. 2012. Status and potential of biogas energy from animal wastes in Turkey. Renewable and Sustainable Energy Reviews 16: 1557-1561. 